Hardiyanti Rahmah.: Penerapan Aspek Kesejahteraan Psikologis Dan Pemaafan Dalam Membentuk Kesehatan Mental

\title{
PENERAPAN ASPEK KESEJAHTERAAN PSIKOLOGIS DAN PEMAAFAN DALAM MEMBENTUK KESEHATAN MENTAL
}

\author{
Hardiyanti Rahmah \\ rahmah.anwar@yahoo.co.id
}

\begin{abstract}
Abstrak
Kesehatan mental merupakan salah satu kunci untuk menjalani hidup dengan lebih produktif. Terutama pada individu yang memiliki risiko terkena gangguan mental, maka pelayanan kesehatan mental sangat diperlukan untuk meningkatkan kesejahteraan psikologis dan pemaafan pada diri mereka. Peneliti menggunakan studi literatur dalam metode penelitian ini. Studi literatur ini berfokus untuk membahas aspek-aspek kesejahteraan psikologis dan pemaafan dalam membentuk kesehatan mental yang positif. Hasil pembahasan pada studi literatur ini dianalisis dari beberapa jurnal dan buku teks yang berkaitan dengan variabel kesejahteraan psikologis, pemaafan dan kesehatan mental yang saling berkaitan satu sama lain.
\end{abstract}

Kata Kunci: Kesejahteraan psikologis; pemaafan; kesehatan mental

\section{A. Pendahuluan}

Masalah kesehatan mental pada umumnya terjadi di kalangan remaja dan biasanya muncul dimulai pada usia 7 tahun. Adapun faktor yang berisiko membuat individu bermasalah secara mental ialah dikarenakan kurangnya penerimaan masyarakat sosial, orang tua yang tidak memiliki pekerjaan dan kesalahan pola asuh (Keyes, 2005ㄹ Stagman \& Cooper, $2010)^{2}$.

Kesehatan mental disebut sebagai ilmu yang memperhatikan perawatan mental atau jiwa. Kesehatan mental sifatnya lebih ke arah preventif dengan tujuan untuk memelihara kesehatan dan efisiensi mental. Individu yang sehat secara mental akan mampu memahami dirinya sendiri

\footnotetext{
${ }^{1}$ Keyes, C. L. M. (2005). Mental illness and/or mental helath? Investigating axioms of the complete state model of health. Journal of Counsulting and Clinical Psychology, 73, 3, 539-548.

${ }^{2}$ Stagman, S., \& Cooper, J. L. (2010). Children's mental health: what every policymaker should know. National Center for Children in Poverty. Columbia : NCCP.
}

Jurnal Ilmiah Al QALAM, Vol. 11, No. 24, Juli-Desember 2017 
Hardiyanti Rahmah.: Penerapan Aspek Kesejahteraan Psikologis Dan Pemaafan Dalam Membentuk Kesehatan Mental

dengan lebih baik dan memiliki pemahaman yang mendalam tentang kelebihan dan kekurangan yang dimiliki (Semiun, 2010) ${ }^{3}$.

Kesehatan mental memiliki beberapa prinsip dasar berikut, yaitu yang pertama kesehatan mental berarti terlepas dari perilaku yang abnormal pada inividu, sehingga orang yang dikatakan sehat mentalnya merupakan individu yang normal. Kedua kesehatan mental merupakan konsep yang ideal dimana individu akan berusaha untuk mencapai kondisi sehat yang maksimal. Ketiga kesehatan mental sebagai bagian dari karakteristik kualitas hidup, hal ini akan menunjukkan bahwa individu dengan kualitas hidup yang baik memiliki kesehatan mental yang baik pula (Latipun \& Notosoedirjo, 2014) ${ }^{4}$.

Pada beberapa penelitian menunjukkan bahwa kondisi kesehatan mental pada individu merupakan sehat secara fisik dan juga psikologis. Sehingga penting untuk mengetahui tentang kesejahteraan psikologis dalam perspektif kesehatan mental. Mental yang sehat dapat terwujud dengan adanya kesadaran pada individu terhadap kesejahteraan dirinya dengan cara mengetahui kemampuan yang dimiliki, mengatasi tekanan-tekanan yang muncul dalam kehidupan, bekerja secara produktif, serta bisa memberikan kontribusi yang positif bagi diri sendiri dan masyarakat.

Selain kesejahteraan secara psikologis, maka individu yang sehat mentalnya memiliki tingkat pemaafan yang bagus terhadap orang lain. Individu yang mampu memaafkan kesalahan dari siapapun maka akan membentuk pola pikir positif dalam dirinya, sehingga dia terbebas dari rasa bersalah, rasa marah dan emosi negatif lainnya yang mungkin akan

\footnotetext{
${ }^{3}$ Semiun, Y. Kesehatan mental 1: Pandangan umum mengenai peneysuaian diri dan kesehatan mental serta teori-teori yang terkait. Yogyakarta : Kanisius, 2010.

${ }^{4}$ Latipun \& Notosoedirjo, M. Kesehatan mental konsep dan penerapan. Edisi 4. UMM Press : Malang, 2014.
}

Jurnal Ilmiah Al QALAM, Vol. 11, No. 24, Juli-Desember 2017 
Hardiyanti Rahmah.: Penerapan Aspek Kesejahteraan Psikologis Dan Pemaafan Dalam Membentuk Kesehatan Mental

memunculkan masalah pada kesehatan mental (Bono, McCullogh \& Root, $2007)^{5}$.

Pentingnya kesejahteraan piskologis dan pemaafan dalam membentuk individu yang sehat secara mental, maka dua faktor ini akan dibahas lebih lanjut pada studi ini, untuk mengetahui bagaimana aspekaspek kesejahteraan psikologis dan pemaafan tersebut berperan dalam membentuk kesehatan mental seseorang.

Prevalensiorang-orang yang memiliki gangguan mental emosional di Indonesia per Oktober 2014 yang lalu sekitar 10 juta jiwa dan 400 ribu mengalami gangguan mental berat atau schizoprenia.Secara nasional riset kesehatan dasar (Rikesda) pada tahun 2013 menyebutkan bahwa sekitar $0,17 \%$ penduduk memiliki masalah mental yang cukup berat, karena itu penting bagi masyarakat menyadari bahwa memiliki kesejahteraan secara fisik dan psikis akan membantu tumbuhnya kesehatan mental yang lebih positif (Budijanto, 2014) ${ }^{6}$.

Berbagai faktor yang melatarbelakangi seseorang terkena masalah atau gangguan mental disebabkan oleh tekanan yang muncul baik dari lingkungan ataupun diri sendiri. Beberapa contoh penyebabnya adalah karena gangguan kepribadian, selalu merasa curiga atau berpikir negatif, kecenderungan narsistik dan adanya permasalahan dalam hubungan antar pasangan, orangtua dan anak, atasan dan bawahan, serta antar teman atau

${ }^{5}$ Bono, G., McCullogh, M. E., \& Root, L. M. Forgiveness, feeling connected to others, and well-being: Two longitudinal studies. (Society for Personality and Social Psychology, 20, 10, 1-14, 2007).

${ }^{6}$ Budijanto, D. 400 Ribu alami gangguan jiwa berat (schizoprenia), 10 juta alami gangguan mental emosional (GME). (online). http.//m.kompasiana.com/post/ diakses 02 Mei 2015.

Jurnal Ilmiah Al QALAM, Vol. 11, No. 24, Juli-Desember 2017 
Hardiyanti Rahmah.: Penerapan Aspek Kesejahteraan Psikologis Dan Pemaafan Dalam Membentuk Kesehatan Mental

lingkungan masyarakat di daerah tempat tinggal (Karremas, Lange \&Ouwerkerk, 20037 ; Worthington, Witvliet, Pietrini \& Miller, $2007^{8}$ ).

Bagi orang-orang yang memiliki kesejahteraan psikologis yang baik dan sifat pemaaf yang tinggi mungkin permasalahan-permasalahan yang muncul karena tekanan serta konflik tidak membuat mereka terganggu secara mentalnya, namun orang-orang yang memang sejak awal berisiko terkena gangguan mental, maka tekanan dan konflik yang muncul walau kecil dapat memicu permasalahan pada mental mereka. Hal tersebut menjadi pembahasan yang penting agar bisa dilakukan pencegahan sejak awal, dengan cara meningkatkan kesejahteraan psikologis individu dan menumbuhkan sifat pemaaf dalam diri mereka yang memiliki risiko tinggi tersebut (Toussaint, Shields, Dorn \& Slavich, 2014) ${ }^{9}$.

\section{B. Kesejahteraan Psikologis}

Kesejahteraan psikologis merupakan suatu konsep kesejahteraan yang mencangkup dimensi subjektif, sosial dan psikologis serta perilaku yang berhubungan dengan kesejahteraan pada diri seseorang. Aspek-aspek pada kesejahteraan psikologis tersebut terdiri dari 6 dimensi yang masingmasing memiliki peran penting terhadap pembentukan kesejahteraan pada individu (Dodge, Daly, Huyton, \& Sanders, 2012) ${ }^{10}$.

${ }^{7}$ Karremas, J. C., Lange, P. A. M. V, \& Ouwerkerk, J. W. When forgiving enhances psychological well-being: The role of interpersonal commitment. (Journal of Personality and Social Psychology, 84, 5, 1011-1026, 2003).

${ }^{8}$ Worthington, E. L., Witvliet, C. V. O., Pietrini, P. \& Miller, A. J. Forgiveness, health, and well-being: A review of evidence for emotional versus decisional forgiveness, dispositional forgivingness, and reduced unforgiveness. (Journal Behavior Med, 30, 291302, 2007).

${ }^{9}$ Toussaint, L., Shields, G. S., Dorn, G. \& Slavich, G. M. Effect of lifetime stress exposure on mental health and physical health in young adulthood: How stress degrades and forgiveness protects health. (Journal of Health Psychology, 1-11, 2014).

${ }^{10}$ Dodge, R., Daly, A., Huyton, J., \& Sanders, L. The challenge of defining wellbeing. (InternationalJournal of Wellbeing, 2, 3, 222-235, 2012).

Jurnal Ilmiah Al QALAM, Vol. 11, No. 24, Juli-Desember 2017 
Hardiyanti Rahmah.: Penerapan Aspek Kesejahteraan Psikologis Dan Pemaafan Dalam Membentuk Kesehatan Mental

Self Acceptance atau penerimaan diri, dimensi ini memiliki karakteristik seperti mampu bersikap positif pada diri pribadi, menerima dan mengakui kondisi atau sikap dirinya baik itu sifat baik atau buruk dan mampu merasa positif terhadap kehidupan di masa lalu (Ryff \& Keyes, $1995)^{11}$.

Positive relation with other atau hubungan positif dengan orang lain, dimensi ini memiliki karakteristik yang mencakup pada adanya keramahan dan kepuasan, menjalin hubungan berdasarkan kepercayaan, perhatian dengan kesejahteraan orang lain, memiliki rasa empati yang bagus, mampu menjalin kedekatan atau keakraban dan memahami aspek timbal balik dalam menjalin hubungan (Ryff \& Keyes, 1995) ${ }^{12}$.

Autonomy atau kemandirian, dimensi ini karakteristiknya adalah kemampuan individu untuk menjadi mandiri, mampu bertahan untuk tetap berpikir saat mendapat tekanan sosial, melakukan tindakan dengan cara yang khusus, mengatur perilaku sesuai dengan dirinya dan mampu mengevaluasi diri pribadi (Ryff \& Keyes, 1995) ${ }^{13}$.

Environmental mastery atau penguasaan terhadap lingkungan, dimensi ini memiliki karakteristik yaitu mampu menguasai dan berkompeten dalam mengatur lingkungan sekitarnya, mampu memanfaatkan setiap kesempatan dengan efektif, mampu menyeleksi hubungan yang sesuai dengan nilai-nilai pribadinya dan mampu mengendalikan aturan yang berasal dari eksternal (Ryff \& Keyes, 1995) ${ }^{14}$.

\footnotetext{
${ }^{11}$ Ryff, C. D. \& Keyes, C. L. M. The structure of psychological well being revisited. (Journal of personality and social psychology, 69, 4, 719-727, 1995). revisited...

${ }^{12}$ Ryff, C. D. \& Keyes, C. L. M. The structure of psychological well being revisited...

${ }^{13}$ Ryff, C. D. \& Keyes, C. L. M. The structure of psychological well being revisited...

${ }^{14}$ Ryff, C. D. \& Keyes, C. L. M. The structure of psychological well being
}

Jurnal Ilmiah Al QALAM, Vol. 11, No. 24, Juli-Desember 2017 
Hardiyanti Rahmah.: Penerapan Aspek Kesejahteraan Psikologis Dan Pemaafan Dalam Membentuk Kesehatan Mental

Porpuse in life atau tujuan hidup, karakteristik dari dimensi ini adalah memiliki tujuan dan perasaan yang terarah dalam hidupnya, memahami makna hidupnya di masa lalu dan masa sekarang, berpegang teguh pada keyakinan yang memberikan makna pada hidupnya dan memiliki tujuan akhir yang jelas dalam hidup (Ryff \& Keyes, 1995) ${ }^{15}$.

Personal growthatau pertumbuhan pribadi, pada dimensi ini memiliki karakteristik berupa adanya perasaan bahwa perkembangan dirinya terus berlanjut, mampu melihat diri sebagai individu yang tumbuh dan berkembang, terbuka dengan setiap pengalaman baru, menyadari bahwa potensi dirinya mampu direalisasikan, muncul perubahan saat bertambahnya pengetahuan pribadi dan mampu memahami setiap perkembangan perilakunya dari waktu ke waktu (Ryff \& Keyes, 1995) ${ }^{16}$.

\section{Pemaafan}

Pemaafan adalah perubahan dari serangkaian perilaku dengan jalan menurunkan motivasi untuk membalas dendam, menjauhkan diri atau menghindar dari pelaku kekerasan dan meningkatkan motivasi atau keinginan untuk berdamai dengan pelaku. Pengertian ini bisa menjadi acuan dalam batasan pemaafan serta pengertian ini juga mencakup dari dua dimensi pemafaan yaitu dimensi intrapsikis dan interpersonal (Worthington \& Scherer, 2004) ${ }^{17}$.

Dimensi intrapsikis yaitu dimensi dimana individu mulai memaafkan dan ketika sudah sepenuhnya memaafkan individu tidak lagi merasa marah

\footnotetext{
revisited...

${ }^{15}$ Ryff, C. D. \& Keyes, C. L. M. The structure of psychological well being revisited...

${ }^{16}$ Ryff, C. D. \& Keyes, C. L. M. The structure of psychological well being

${ }^{17}$ Worthington, E. L. \& Scherer, M. Forgiveness is an emoticon focused coping strategy that can reduce health risks and promote health resilience: Theory, review, and hypotheses. (Psychology and Health, 19, 3, 385-405, 2004).
}

Jurnal Ilmiah Al QALAM, Vol. 11, No. 24, Juli-Desember 2017 
Hardiyanti Rahmah.: Penerapan Aspek Kesejahteraan Psikologis Dan Pemaafan Dalam Membentuk Kesehatan Mental

atau dendam. Dimensi ini melibatkan aspek emosi dan kognisi dari pemaafan.Proses pemaafan pada dimensi ini hanya dilakukan oleh pihak korban yang mencoba berdamai dengan emosinya dan kebanyakan proses pemaafan ini terjadi dengan orang asing atau orang yang tidak diinginkan untuk bisa melanjutkan hubungan interaksi lagi (Fincham, 2002) ${ }^{18}$.

Dimensi interpersonal yaitu dimensi yangmemfokuskan pada perilaku dalam mengekspresikan pemaafan. Perilaku tersebut seperti mengucapkan kalimat, "Saya memafkan kamu". Proses pemaafan pada dimensi ini melibatkan aspek sosial dari pemaafan, yaitu hubungan untuk memaafkan orang lain dengan mengekspresikan kata maaf itu secara langsung (Fincham, 2002) ${ }^{19}$.

Adapun aspek-aspek dari pemaafan itu sendiri terdiri dari 3 aspek yang pada setiap aspeknya menunjukkan bagaimana karakteristik individu dalam upaya untuk memaafkan. Ketiga aspek pemaafan itu sendiri terdiri dari motivasi untuk menghindar, motivasi untuk balas dendam dan motivasi untuk berbaik hati (McCollugh, et al, 1998) ${ }^{20}$.

Avoidance motivation atau motivasi untuk menghindar, ditandai dengan individu yang menarik diri (withdrawal) dari transgressor (orang yang menyakiti). Pada aspek ini motivasi untuk membalas dendam terhadap suatu hubungan menurun, individu yang terluka membuang keinginannya

${ }^{18}$ Fincham, F. D. Forgiveness Integral to Ascience of Close Relationship. Inaugural Herzliya Symposium on Personality and Social Psychology Prosocial Motives, Emotions, and Behavior. Family Institude: Florida State University, 2002.

${ }^{19}$ Fincham, F. D. Forgiveness Integral to Ascience of Close Relationship...

${ }^{20} \mathrm{McC}$ ullogh, M. E., Rachal, K. C., Sandage, S. J., WorthingtonJr, E. L., Brown, S. W. \& Hight, T. L. Interpersonal forgiving in close relationships: II. Theoritical elaborationand measurement. (Journal of Personality and Social Psychology,75, 6, 15861603, 1998).

Jurnal Ilmiah Al QALAM, Vol. 11, No. 24, Juli-Desember 2017 
Hardiyanti Rahmah.: Penerapan Aspek Kesejahteraan Psikologis Dan Pemaafan Dalam Membentuk Kesehatan Mental

untuk membalas dendam terhadap orang yang telah menyakiti, akan tetapi dia cenderung menghindari orang yang menyakitinya tersebut.

Revenge motivation atau motivasi untuk balas dendam, ditandai dengan motivasi individu untuk membalas perbuatan transgressor (orang yang menyakiti) yang ditujukan kepadanya. Dalam kondisi ini motivasi individu untuk menghindari transgressor menurun, individu tersebut marah dan berkeinginan untuk membalas dendam terhadap transgressor.

Benevolence motivation atau motivasi untuk berbaik hati, ditunjukkan dengan motivasi untuk berbuat baik terhadap transgressor. Pada aspek ini individu akan semakin termotivasi pada niat baik dan keinginan untuk berdamai, meskipun kesalahan individu yang akan dimaafkannya itu termasuk tindakan berbahaya. Individu pada aspek ini memiliki keinginan unuk berdamai atau melihat well being orang yang menyakitinya.

\section{Kesehatan Mental}

Mental yang sehat adalah kondisi dimana individu terbebas dari segala bentuk gejala-gejala gangguan atau permasalahan mental. Individu yang sehat secara mental, akan dapat berfungsi secara normal dalam menjalankan hidup, khususnya saat menyesuaikan diri untuk menghadapi masalah-masalah yang ditemui. Kesehatan mental merupakan hal penting yang harus diperhatikan sebagaimana kesehatan fisik. Kesehatan mental yang stabil dan kesehatan fisik yang baik akan saling mempengaruhi.

Kesehatan mental merupakan dasar untuk kesehatan yang baik dalam meningkatkan kualitas hidup. Kesehatan mental merupakan sumber daya bagi kehidupan sehari-hari dan memberikan kontribusi untukfungsi individu, keluarga danmasyarakat yang positif. Menurut World Health

Jurnal Ilmiah Al QALAM, Vol. 11, No. 24, Juli-Desember 2017 
Hardiyanti Rahmah.: Penerapan Aspek Kesejahteraan Psikologis Dan Pemaafan Dalam Membentuk Kesehatan Mental

Organization (WHO) tidak ada kesehatan tanpa jiwa yang sehat (Barry, $2009)^{21}$.

Literatur kesehatan mental telah difokuskanterutama pada studi dan pengobatan terhadap gangguan mental yang telah dipahami sebagai fenomena medis, psikologis dan sosiologis. Kesehatan mental yang positif sejalan dengan perspektif promosi kesehatan dan berfokus pada kesehatan positif yang mencegah dari penyakit.Munculnya bidang-bidang seperti psikologi positif dan pengembangan kesejahteraan pada kesehatan mental semakin mendukung tingkat promosi kesehatan (Barry, 2009) ${ }^{22}$.

\section{E. Metode Penelitian}

Metode penelitian yang digunakan yaitu penelitian kualitatif berbasis studi literatur atau studi pustaka. Hasil penelitian didapatkan dengan mengkaji dan menggali berbagai teori melalui beberapa literatur mulai dari buku, jurnal ilmiah, e-book, internet dan berbagai data serta fakta yang ada dalam masyarakat (Moleong, 2014) ${ }^{23}$.

Studi literatur adalah bagian dari telaah ilmu yang memfokuskan pada persepsi dan lebih merupakan olahan filosofik dan teoritik, daripada olahan validasi empirik dan terkait nilai (Muhadjir, 1996) ${ }^{24}$. Alasan dari penggunaan metode penelitian ini sebagai pendukung tujuan penulisan, yaitu untuk membandingkan beberapa paradigma keilmuan yang berbeda.

\footnotetext{
${ }^{21}$ Barry, M. M. Addressing the determinants of positive mental health: Concepts, evidence and practice. (International Journal of Mental Health Promotion, 11, 3, 4-17, 2009).

${ }^{22}$ Barry, M. M. Addressing the determinants of positive mental health: Concepts, evidence and practice...

${ }^{23}$ Moleong, L. J. Metodologi Penelitian Kualitatif. (Bandung : ROSDA. 2014).

${ }^{24}$ Muhadjir, N. Metodologi Penelitian Kualitatif. (Yokayakarta : Rake Sarasin. 1996).
}

Jurnal Ilmiah Al QALAM, Vol. 11, No. 24, Juli-Desember 2017 
Hardiyanti Rahmah.: Penerapan Aspek Kesejahteraan Psikologis Dan Pemaafan Dalam Membentuk Kesehatan Mental

\section{F. Hasil Penelitian}

Individu yang memiliki pandangan positif terhadap hidup akan memiliki kesehatan mental yang positif pula, sehinga dengan terbentuknya penerimaan yang baik terhadap dirinya baik dalam hal kelebihan ataupun kekurangan, serta kemampuan individu dalam menjalin hubungan baik terhadap orang lain dan kemandirian dalam mengatasi setiap masalah yang dialaminya akan menumbuhkan pemikiran yang positif dan menjadi upaya dalam menumbuhkan kesehatan mental yang baik bagi individu tersebut.

Adapun kemampuan individu dalam berbaur di lingkungannya dan berkompeten dalam mengatur orang-orang yang ada di dalamnya, kematangan individu dalam tujuan hidup yang dimiliki sehingga mampu memberi makna positif terhadap kehidupan yang sudah dilalui dan yang akan dijalaninya, serta pertumbuhan pribadi yang menguatkan potensi yang dia miliki untuk lebih mengembangkan diri akan menjadi pendukung yang kuat dalam pembentukan mental yang positif pada diri individu.

Pada aspek-aspek kesejahteraan psikologis ini maka kesehatan mental yang dibentuk adalah bagian dari pengembangan diri individu secara personal maupun sosial. Secara personal, individu memiliki pandangan yang positif terhadap dirinya pribadi, potensinya dan kehidupan di masa lalu dan masa depannya. Secara sosial, individu memiliki kemampuan untuk berinteraksi dan menjalin hubungan baik pada orang lain.

Selain aspek kesejahteraan psikologis, aspek pemaafan memiliki pengaruh dalam membentuk kesehatan mental. Pemaafan dapat berfungsi dengan baik sebagai penangkal stres, permusuhan, dan penurunan kesehatan, juga untuk proses mempromosikan kesehatanpositif emosi lainnya yang berorientasi pada kesehatan mental. Pemaafan akan memiliki manfaat yang positif jika difungsikan secara maksimal pada setiap individu,

Jurnal Ilmiah Al QALAM, Vol. 11, No. 24, Juli-Desember 2017 
Hardiyanti Rahmah.: Penerapan Aspek Kesejahteraan Psikologis Dan Pemaafan Dalam Membentuk Kesehatan Mental

yaitu saat individu mampu memaafkan dan mempunyai keinginan yang tulus untuk berdamai dengan individu lain yang telah menyakitinya (Worthington, et al, 2007²5; Asgari \& Roshani, 2013 ${ }^{26}$ ).

Pembentukan pada cara atau kondisi individu dalam memaafkan orang yang menyakitinya atau transgressormungkin tidak langsung mencapai aspek ketiga, yaitu individu mampu memaafkan dan mampu berbuat baik pada transgressor. Beberapa individu akan mampu memaafkan tapi masih berupaya untuk menghindaritransgressor walaupun sudah tidak ada motivasi untuk membalas dendam.

Pada kondisi yang lain, individu mungkin tidak menghindari transgressornamun masih memiliki keinginan untuk membalas dendam terhadap transgressor. Kondisi ini belum sampai pada bentuk perilaku balas dendam dari individu yang tersakiti.Individu hanya masih memiliki dendam, sehingga saat memberikanpemaafan pada individu yang tersakiti cenderung masih diikuti dengan perasaan marah.

Adapun individu yang mampu memaafkan pada kondisi sudah bisa berbuat baik pada transgressor, pada awalnya mungkinmasih menghindaritransgressor atau masih punya keinginan untuk membalas dendam kepada transgressor, namun setelah beberapa waktu yang dilalui, individu mampu berada pada kondisi ketiga yaitu memaafkan dengan damai. Adapula yang bisa memaafkan dan langsung berbuat baik terhadap transgressor. Kondisi ini tergantung pada bagaimana individu memandang

${ }^{25}$ Worthington, E. L. Worthington, E. L., Witvliet, C. V. O., Pietrini, P. \& Miller, A. J. Forgiveness, health, and well-being: A review of evidence for emotional versus decisional forgiveness, dispositional forgivingness, and reduced unforgiveness. (Journal Behavior Med, 30, 291-302, 2007).

${ }^{26}$ Asgari, P. \& Roshani, K. ( 2013). Validation of forgiveness scale and a survey on the relationship of forgiveness and student mental health. International Journal of Psychology and Behavioral Research.2, 2, 109-115.

Jurnal Ilmiah Al QALAM, Vol. 11, No. 24, Juli-Desember 2017 
Hardiyanti Rahmah.: Penerapan Aspek Kesejahteraan Psikologis Dan Pemaafan Dalam Membentuk Kesehatan Mental

permasalahan yang dihadapi. Individu dengan pemikiran yang positif akan mudah dalam memaafkan transgressorwalaupun kesalahannya terhadap individu tersebut sudah ke arah tindakan yang berbahaya.

Pada pembentukkan kesehatan mental yang positif maka motivasi untuk berbaik hati terhadap orang yang telah menyakiti individu merupakan kemampuan memaafkan yang sangat baik. Sehingga dari ketiga aspek pemaafan yang terdiri dari motivasi untuk menghindar, motivasi untuk membalas dendam dan motivasi untuk berbaik hati, maka yang memiliki peran besar dalam upaya membentuk kesehehatan mental yang positif adalah aspek ketiga yaitu proses memaafkan dengan kembali membangun hubungan baik.Cara yang dilakukan pada aspek ketiga ini misalnya, individu berbuat kebaikan kepada orang yang telah menyakitinya tanpa ada keinginan untuk menghindar ataupun balas dendam.

\section{G. Kesimpulan}

Kesejahteraan psikologis dan pemaafan merupakan faktor pendukung yang positif dalam pembentukan kesehatan mental individu. Hal tersebut dikarenakan saat individu mampu memaafkan dengan motivasi berbuat baik, maka akan membentuk psikis yang sejahtera yaitu berupa ketenangan dan kedamaian, serta mampu membentuk hubungan yang lebih positif pada lingkungan sekitarnya.

Beberapaupaya untuk meningkatkan kesehatan mental pada diri individu yang cukup efektif yaitu dengan menumbuhkan kesejahteraan psikologis yang baik terlebih dahulu, sehingga penerimaan individu terhadap dirinya sendiri, rekan atau relasi dan lingkungannya akan selalu positif. Selain itu, sifat pemaaf yang tumbuh dengan baik pada diri individu akan mampu membentuk individu yang tidak pendendam dan memunculkan

Jurnal Ilmiah Al QALAM, Vol. 11, No. 24, Juli-Desember 2017 
Hardiyanti Rahmah.: Penerapan Aspek Kesejahteraan Psikologis Dan Pemaafan Dalam Membentuk Kesehatan Mental

emosi positif. Hal ini akan mampu menumbuhkan jiwa atau mental yang sehat dan positif

Jurnal Ilmiah Al QALAM, Vol. 11, No. 24, Juli-Desember 2017 119 
Hardiyanti Rahmah.: Penerapan Aspek Kesejahteraan Psikologis Dan Pemaafan Dalam Membentuk Kesehatan Mental

\section{Daftar Pustaka}

Asgari, P. \& Roshani, K. Validation of forgiveness scale and a survey on the relationship of forgiveness and student mental health. International Journal of Psychology and Behavioral Research.2, 2, 109-115, 2013.

Barry, M. M. Addressing the determinants of positive mental health: Concepts, evidence and practice. International Journal of Mental Health Promotion, 11, 3, 4-17, 2009.

Bono, G., McCullogh, M. E., \& Root, L. M. Forgiveness, feeling connected to others, and well-being: Two longitudinal studies. Society for Personality and Social Psychology, 20, 10, 1-14, 2007.

Budijanto, D. 400 Ribu alami gangguan jiwa berat (schizoprenia), 10 juta alami gangguan mental emosional (GME). (online). 2014. http.//m.kompasiana.com/post/ diakses 02 Mei 2017.

Dodge, R., Daly, A., Huyton, J., \& Sanders, L. The challenge of defining wellbeing. InternationalJournal of Wellbeing, 2, 3, 222-235, 2012.

Fincham, F. D. Forgiveness Integral to Ascience of Close Relationship. Inaugural Herzliya Symposium on Personality and Social Psychology Prosocial Motives, Emotions, and Behavior. Family Institude: Florida State University.2002.

Karremas, J. C., Lange, P. A. M. V, \& Ouwerkerk, J. W. When forgiving enhances psychological well-being: The role of interpersonal commitment. Journal of Personality and Social Psychology, 84, 5, 1011-1026, 2003.

Keyes, C. L. M. Mental illness and/or mental helath? Investigating axioms of the complete state model of health. Journal of Counsulting and Clinical Psychology, 73, 3, 539-548, 2005.

Latipun \& Notosoedirjo, M. Kesehatan mental konsep dan penerapan. Edisi 4. Malang : UMM Press. 2014.

McCullogh, M. E., Rachal, K. C., Sandage, S. J., WorthingtonJr, E. L., Brown, S. W. \& Hight, T. L. Interpersonal forgiving in close relationships: II. Theoritical elaborationand measurement. Journal of Personality and Social Psychology,75, 6, 1586-1603, 1998.

Moleong, L. J. Metodologi Penelitian Kualitatif. ROSDA : Bandung. 2014.

Muhadjir, N. Metodologi Penelitian Kualitatif. Rake Sarasin : Yokayakarta. 1996.

Jurnal Ilmiah Al QALAM, Vol. 11, No. 24, Juli-Desember 2017 
Hardiyanti Rahmah.: Penerapan Aspek Kesejahteraan Psikologis Dan Pemaafan Dalam Membentuk Kesehatan Mental

Ryff, C. D. \& Keyes, C. L. M. The structure of psychological well being revisited. Journal of personality and social psychology, 69, 4, 719-727, 1995.

Semiun, Y. Kesehatan mental 1: Pandangan umum mengenai peneysuaian diri dan kesehatan mental serta teori-teori yang terkait. Yogyakarta : Kanisius.2010.

Stagman, S., \& Cooper, J. L. Children's mental health: what every policymaker should know. National Center for Children in Poverty. Columbia : NCCP. 2010.

Toussaint, L., Shields, G. S., Dorn, G. \& Slavich, G. M. Effect of lifetime stress exposure on mental health and physical health in young adulthood: How stress degrades and forgiveness protects health. Journal of Health Psychology, 1-11, 2014.

Worthington, E. L. \& Scherer, M. Forgiveness is an emoticon focused coping strategy that can reduce health risks and promote health resilience: Theory, review, and hypotheses. Psychology and Health, 19, 3, 385-405, 2004.

Worthington, E. L., Witvliet, C. V. O., Pietrini, P. \& Miller, A. J. Forgiveness, health, and well-being: A review of evidence for emotional versus decisional forgiveness, dispositional forgivingness, and reduced unforgiveness. Journal Behavior Med, 30, 291-302, 2007.

Jurnal Ilmiah Al QALAM, Vol. 11, No. 24, Juli-Desember 2017 
Hardiyanti Rahmah.: Penerapan Aspek Kesejahteraan Psikologis Dan Pemaafan Dalam Membentuk Kesehatan Mental

Jurnal Ilmiah Al QALAM, Vol. 11, No. 24, Juli-Desember 2017 122 